\title{
A Review of the Toxicants Found in World Trade Center Dust
}

\author{
Bernadette Royce ${ }^{1,2}$, Ira S. Richards ${ }^{1}$ \\ ${ }^{1}$ University of South Florida College of Public Health, Department of Environmental and Occupational Health \\ ${ }^{2}$ Commonwealth Health Emergency Medical Services \\ Firemed258@gmail.com \\ irichard@health.usf.edu
}

Abstract: The collapse of the World Trade Center Twin Towers and World Trade Center Building 7 resulted in a cataclysmic release of dust, now called World Trade Center (WTC) dust, in Lower Manhattan and the surrounding communities. Approximated one million tons of dust and smoke were released. A number of toxicants with known adverse health outcomes were found in the dust. These chemicals include polycyclic aromatic hydrocarbons (PAHs), pesticides, and polychlorinated biphenyls (PCBs), many of which are known carcinogens. Other organic compounds detected included phthalate esters and polychlorinated dibenzop-diozins (PCDDs) and dibenzofuroans (PCDFs). Asbestos was also identified in the dust. In recent years, a number of adverse health outcomes have been associated with exposure to the WTC dust. These adverse health outcomes include respiratory disease, cardiovascular disease, cancer, and autoimmune disorders. This paper offers a short review of the toxicants found in the WTC dust.

Keywords: World Trade Center dust, asbestos, particulate matter

On September 11, 2001, now commonly known as 9/11, the United States suffered a terroristic attack, which resulted in the death of 2,996 individuals. During the terrorist attacks, four airliners were hijacked and used as weapons. Two of the airliners, American Airlines Flight 11 and United Airlines Flight 175, crashed into the North and South Towers of the World Trade Centers. As the Twin Towers of the World Trade Center, as well as World Trade Center Building 7 collapsed, a cataclysmic release of dust, now called World Trade Center dust, occurred in Lower Manhattan and the surrounding communities. The catastrophic collapse of the Twin Towers and WTC 7 released approximately one million tons of dust and smoke (Pliel et al, 2004). WTC dust was a complex mixture of pulverized buildings and their contents, jet fuel, asbestos, cremated human remains and other components. In the seventeen years since the devastating events of $9 / 11$, multiple adverse health outcomes have been associated with exposure to the WTC dust. These adverse health outcomes include cancer, respiratory disease, cardiovascular disease, and autoimmune disease (Gargana et al, 2008). As the mortality and morbidity associated with exposure to WTC dust and the events of 9/11 continue to increase, a review of the toxicants found in WTC dust and the known harmful effects of these toxicants may be helpful to review.

When the collapses of the buildings occurred, the dust blanketed Lower Manhattan. However, the other surrounding communities were also impacted by the exposure. The dust traveled immediately in all directions. For the next 18 hours, the plume travelled east and then southeast (Lioy et al, 2002). The collapse "occurred at velocities over 150 miles per hour, pulverizing computers, wallboard, steel fixtures, glass, and so on, releasing a dust mixture over $90 \%$ of which was greater than $10 \mu \mathrm{m}$; yet there were 11,000 tons of [particulate matter $\left._{2.5}\right]^{\prime \prime}$ (Rom et al, 2010).

In addition to the WTC dust from the collapse, fine particles were continuously released as a result of the fires which burned until December 19,2001. The airplanes contained approximately 91,000 liters of jet fuel. The fires 
also consumed approximately 100,000 tons of organic debris, 490,000 liters of transformer oil and 380,000 liters of heating and diesel oil. There were also several thousand vehicles, which also contained fuel, stored in the underground structures of the WTC. These fires would produce the classic products of incomplete combustion, including polycyclic aromatic hydrocarbons (PAHs). Even once the fires were extinguished, particulate matter (PM) and PAHs continued to be generated as a result of diesel exhaust from the clean-up operation which continued until May, 2002 (Pliel et al, 2004).

The WTC dust was primarily composed of large particles of cement and gypsum and was extremely alkaline in nature. It was very light and fluffy and ranged in color from white to pinkish-grey. The $\mathrm{pH}$ of the dust ranged from 9.0-11.5 in settled samples (Lioy et al, 2002; Landrigan et al, 2004). When the dust came into contact with water, either from rain, wash water or moisture in the eyes and upper respiratory system, the dust became chemically reactive. The alkalinity of the dust and the large amount of pulverized concrete, gypsum and cement is believed to be the likely cause of the acute complaints of inhalation hazards at Ground Zero, as the WTC site became known (McGee et al, 2003).

The dust contained a significant number of chemicals of potential concern (COPC). Among these were PAHs, pesticides, and polychlorinated biphenyls (PCBs), many of which are known carcinogens. Other organic compounds detected included phthalate esters and polychlorinated dibenzo-p-diozins (PCDDs) and dibenzofuroans (PCDFs). Asbestos was also identified in the dust (Lioy, 2002). Exposure to the dust has been shown to decrease cell proliferation and increase apoptosis. According to the Lambroussis et al (2009), "the results indicate that low doses of [WTC dust] influence cell viability and stimulate an increase in apoptosis levels as well. This data correlates with the lung damage that is now linked to rescuers that worked at the WTC site following the tragedy."

\section{Polycyclic Aromatic Hydrocarbons}

Polycyclic Aromatic Hydrocarbons (PAHs) comprise over 100 various chemicals formed by the incomplete combustion of organic matter. PAHs can attach to particulate matter and be inhaled. Their association with skin cancer, lung cancer, and bladder cancer has been well-documented (Boffetta et al, 1997). According to Kriek et al (1998), PAHs may lead to DNA-adduct formation. These PAH-DNA adducts indicate possible cancer risk; their formation is a necessary step in carcinogenesis and both epidemiological and experimental research has shown increased cancer risk associated with their formation (Perera et al, 2005a). Other research has shown that PAH exposure may result in p53 mutations (Alexandrov et al, 2002).

Offenberg et al (2002) estimated that on September 11,2001,100-1000 tons of PAHs were immediately dispersed over an unknown area. According to Pliel et al (2004), on September 14, 2001, the predicted concentrations of PAHs in the air at Ground Zero ranged between 1.3 to $5 \mathrm{ng} / \mathrm{m}^{3}$. According to the dust samples collectedin the days immediately following $9 / 11$, approximately $0.4 \%$ of the dust consisted of 37 different PAHs (Lioy et al, 2002). The PAHs in the first 100 days resulted from the fires; after that, the diesel exhaust from the equipment used in the clean-up effort was the main source of the PAHs (Pliel et al, 2004; Olson \& Norris, 2008).

Pliel et al (2006), however, did note that random samples taken 3.5 years after 9/11 of mostly residential spaces located near the WTC site did not contain PAH levels that were statistically higher than that of urban background contamination.

Benzo[a]pyrene (BaP) was one PAH found at Ground Zero. BaP is one of the PAHs which are carcinogenic, mutagenic and a developmental toxicant. BaP is the most extensively studied carcinogen in cigarette smoke and has been long known to be involved in the causation of lung cancer" (Alexandrov et al, 2002). Perera et al (2005b) examined the levels of BaP-DNA adducts in four populations of women and their newborns. These populations consisted of residents of Northern Manhattan, participants in a study on the health effects of the WTC disaster, residents of Krakow, Poland and residents of Tongliang, China. The residents of Northern Manhattan 
had significantly lower levels of BaP-DNA adducts than did the WTC study participants $(36.8 \%$ of women in Northern Manhattan compared to 57.5\% from the WTC study). However, women from the other populations still had higher levels. $72.9 \%$ of women from Krakow had detectable levels and $73.4 \%$ of women from Tongliang had detectable levels. The following levels of detectable adducts were discovered in the newborns: Northern Manhattan 42.4\%; WTC study 60.6\%; Krakow 71.7\%; and Tongliang 79.5\%. Perera et al (2007) also concluded that higher levels of BaP-DNA adducts may lead to a modest reduction in cognitive development by the age of three in children exposed in utero.

\section{Volatile ORGanic Compounds}

According to the Agency for Toxic Substances and Disease Registry (ATSDR, 2008), volatile organic compounds (VOCs) are those compounds that contain carbon and evaporate easily. Benzene is a VOC and a known human carcinogen. The International Agency for Research on Cancer (IARC, 2012) classifies benzene as a Group 1 Carcinogen, indicating such. The National Toxicology Program (NTP) lists benzene as a Group A Carcinogen, also recognizing that it is a human carcinogen. The primary mechanism for exposure to benzene and VOCs is inhalation (NTP, 2011). While dioxin can be absorbed on PM, benzene cannot. The primary source of benzene at Ground Zero was the jet fuel from the planes. The levels of benzene reached up to $180,000 \mathrm{ppb}$ within the actual work area of Ground Zero. Outside the perimeter, the levels dropped to 20ppb. On October 3, 2001, the levels at WTC North Tower, the levels ranged from 28,000-39,000ppb. The WTC South Tower levels were 4,300ppb. At Liberty and Greenwich Streets, the levels dropped to less than 20ppb (US EPA, 2003a).

One study examined the levels of benzene at four sites near Ground Zero. Of the four sites monitored, Site N (intersection of West Broadway and Park Place) had the highest concentration of benzene with a range of 0.9 to 83.0 and a mean of 9.9 (SD 16.2) $\mathrm{mcg} / \mathrm{m}^{3}$. Site NE (US EPA Region Building 2 at 290 Broadway) had the lowest concentration (0.7-23.1, mean 5.1, SD $6.4 \mathrm{mcg} / \mathrm{m}^{3}$ ) (Olson et al, 2003).

Toluene also was found in the highest concentrations at Site N. The range was 1.2 to 59.4 was a mean of 13.9 (SD 12.8) $\mathrm{mcg} / \mathrm{m}^{3}$. Site NE had the lowest levels with a range of 0.8 to 13.9 and a mean of 5.9 (SD 4.4 ) $\mathrm{mcg} / \mathrm{m}^{3}$ (Olson et al, 2003). Toluene is not considered carcinogenic; however, research has indicated that it may have synergistic properties with benzene. Toluene is a neurotoxicant; however, unlike benzene, it has not previously been shown to have negative effects on the airway. A study by Pariselli et al (2009) examined the effects of toluene and benzene exposure to human epithelial lung cells as both individual compounds and as a mixture. DNA damage as a result of toluene exposure began to repair itself within 24 hours. However, exposure to a mixture of the chemicals resulted in a cytotoxic effect and DNA damage. The authors concluded that the repair of the DNA damage caused by toluene was suppressed in the presence of benzene.

\section{Particulate Matter}

Particulate matter (PM) refers to solid particles and liquid droplets in the air that can be inhaled. Fine particulate matter refers to PM with a mass medial aerodynamic diameter (MMAD) $<2.5$ micrometers $\left(\mathrm{PM}_{2.5}\right)$. Coarse PM is $>2.5$ and $<10$ micrometers $\left(\mathrm{PM}_{2.5-10}\right)$ and larger PM is greater than 10 micrometers in size. $\mathrm{PM}_{2.5-10}$ has been shown to have adverse health outcomes since it can be inhaled due to its small size. On average, the smaller the size of the particle, the deeper it enters the airway (McGhee et al, 2003) PM exposure is associated with premature mortality, likely from its effects on the cardiovascular and respiratory systems (Pelucchi, 2009).

According to McGhee et al (2003), the majority of $\mathrm{PM}_{2.5}$ was associated with pulverized building material, rather than products of incomplete combustion. The $\mathrm{pH}$ of the $\mathrm{PM}_{2.5}$ ranged from 8.88 to 10.00 , consistent with the alkaline nature of the building materials. The authors concluded that the inhalation hazard of $\mathrm{PM}_{2.5}$ from the WTC was due to the presence of gypsum, calcite, cemete and concrete. Olson \& Norris (2008) further elucidated that the sources of $\mathrm{PM}_{2.5}$ included open burning, smoldering, mixed recovery sources, a sulfate/debris mix and motor exhaust. 
According to weight of the settled dust, $96 \%$ of it was $>10$ micrometers MMAD. $\mathrm{PM}_{2.5}$ was $<1.0 \%$ by weight and fine PM was $0.5 \%-0.4 \%$ by weight. "However, settled dust may not accurately represent the relative proportions of airborne respirable particles following the collapse of the towers. Small particles may coalesce or agglomerate to form larger particles, altering the relative proportions of fine and coarse particles" (Szeinuk et al, 2008)

A specific type of PM is residual oil fly ash (ROFA). ROFA consists of a significant quantity of transition metals, such as vanadium (V), nickel ( $\mathrm{Ni}$ ) and iron ( Fe). The bioavailability of these metals is associated with both lung and cardiovascular injury. These metals are a significant aspect of the toxicity of ROFA. A study conducted by the Gavett et al (2003) on airway inflammation in mice used ROFA as a toxic control because of its ability to cause significant airway inflammation. WTC $\mathrm{PM}_{2.5}$ led to a much greater degree of airway hyperresponsiveness in the mice than ROFA. The dose required was a relatively high dose; however, many individuals present in the early hours following the collapse did possibly receive a high dose of WTC $\mathrm{PM}_{2.5}$. A healthy person would require $425 \mathrm{mcg} / \mathrm{m}-3$ for eight hours to equal this dose. In the hours following the collapse, this level was present in the air for the rescue workers. The authors commented that obviously the initial injury appeared to impact the recovery aspect; the firefighters present for the collapse sustained a significant initial injury.

\section{DIOXINS AND FURANS}

While there are 29 congeners that are considered dioxin-like, measurements near the WTC site included only the 17 polychlorinated dioxin and furan congeners. Dioxin is a persistent toxin in the environment and causes significant adverse effects in both wildlife and humans. The adverse effects are widespread and include cardiovascular disease, metabolic derangements, endometriosis, cancer, integumentary disease, immunological issues and endocrine disruption (White \& Birnbaum, 2009). Specifically, "dioxin exposure is associated with increased cancer mortality, and increased rates of soft tissue sarcoma, lymphoma and respiratory tract cancers have been been seen in individuals with significant dioxin exposure" (Moline et al, 2006).

Results of one study measuring plasma levels possibly indicate that WTC responders were exposed to PCDFs after the collapse of the buildings (Horii et al, 2010). Another preliminary health risk assessment conducted six weeks following $9 / 11$ used the window films on building exteriors near the WTC site to determine concentration of polychlorinated dibenzo-p-dioxins and dibenzofurans (PCDD/Fs). The window film samples were compared to background levels in Manhattan and Brooklyn. The results indicated levels up to 2.6 times greater than the background levels (Rayne, 2005).

Butt et al (2004) also measured window films six weeks after the attacks. The total sum of PBDE, PCB, PCN and PAH window film concentrations were highest approximately one kilometer from the WTC site; however, by 3.5 kilometers from the site, the levels had rapidly decreased to almost background levels. Rayne et al (2005) also wrote that within a one kilometer area the total PCDD/F mass concentration had a toxic equivalent concentration (TEQ) of $4700 \mathrm{TEQ} / \mathrm{m}^{2}$. Approximately 3.5 kilometers away from the WTC site, the concentration dropped to $130 \mathrm{pgTEQ} / \mathrm{m}^{2}$.

Before 9/11, Fire Department of New York City (FDNY) members had a significant exposure to PCBs and PCDFs at a Staten Island Transformer Fire on September 7, 1998. A HazMat scene was not declared. Significant levels of PCBs and PCDFs were detected on the firefighters' gloves and gear; however serum PCBs averaged $2.92+/-$ $1.96 \mathrm{ppb}$ (range 1.9-11.0 ppb). This indicated that firefighter gear offered protection from PCBs and PCDFs; however the gear included self-contained breathing apparatus (SCBA) (Kelly et al, 2002). Firefighters did not consistently use SCBA at Ground Zero. Respiratory protection was not immediately available or consistently used for most of the responders at the site (Feldman et al, 2004).

\section{Asbestos}

Asbestos refers to silicate minerals found in fiber forms. They have been mined and commercially used primarily in the forms of serpentine chrysotile asbestos and the amphibole crocidolite, anthophyllite, amosite, actinolite, and tremolite. Fiber length determines the hazards of the asbestos. Asbestosis may result from fibers 
2 micrometers in length. Fibers 5 micrometers in length are related to the development of mesothelioma. Lung cancer develops from fibers longer than 10 micrometers in length. (Witschi et al, 2008). The fibers found at the WTC site were mostly short in length (Landrigan et al, 2004).

Fiber diameter is also crucial to the pathophysiology of asbestos-related disease. A fiber diameter that is greater than 3 micrometers cannot easily penetrate the peripheral lung. For the development of mesothelioma, a fiber diameter must be less than 0.5 micrometers; this is required in order for the fibers to be translocated to other sites by the lymphatic system (Witschi et al, 2008). A fiber recovered by bronchoaveolar lavage (BAL) from an FDNY firefighter was 70micrometers long and less than 0.2 micrometers in diameter (Rom et al, 2002). Asbestos is also associated with pulmonary fibrosis and reduced lung function due to asbestos fibers becoming trapped in the lungs, pleural plaques, thickening of the pleura, pleural calcification and pleural effusions. The synergistic effects of asbestos and PAHs in carcinogenesis have been well documented. (Fournier \&Pezerat, 1986; Moline et al, 2006). Studies have also shown that exposure to asbestos may lead to autoimmune disease (Pfau et al, 2005; Marchanda et al, 2012).

In a 1991 study by Markowitz et al regarding asbestos exposure in FDNY firefighters, the authors discussed possible exposure routes. The authors cautioned "of greatest concern is the possible exposure to asbestos at the site of a fire, since the demolition of buildings during fires may lead to uncontrolled and possibly heavy exposure to asbestos." Asbestos was used in the construction of the WTC towers as a spray-on fire retardant. An estimated 5,000 tons of chrysotile asbestos was used on the lower 40 floors of the towers (Landrigan et al, 2004). Due to the use of asbestos, it was a significant health concern after $9 / 11$. The EPA tested over 10,000 air samples for asbestos (US. EPA, 2003a). Of these samples, 22 contained asbestos levels above the clearance standards of 70 fibers $/ \mathrm{mm}^{2}$. This standard was established in 1986 in the Asbestos Hazard Emergency Response Act (Landrigan et al, 2004).

Samet el al (2007) suggested that these levels of asbestos would be insufficient to cause asbestosis or an increase in lung cancer risk. The excess risk of mesothelioma development would not appear for decades. A risk assessment of asbestos-related cancer from the WTC disaster indicated that the increased risk for lower Manhattan residents from the asbestos exposures actually is negligible (Hitt, 2001; Ilgren, 2001). A study on induced sputum assessment on FDNY firefighters collected ten months after the collapse of the towers did not show any asbestos fibers (Fireman et al, 2004). However, bronchoaveolar lavage (BAL) conducted on an FDNY firefighter did produce asbestos fibers. One firefighter developed acute eosinophilic pneumonia after heavy exposure to WTC dust for 16-hour days from September 11, 2001 to September 24, 2001. The BAL revealed fly ash, degraded glass, and both chrysotile and amosite asbestos fibers.. BAL revealed 70\% eosinophils; his peripheral blood level for eosinophils was $1 \%$. The BAL also revealed 305 asbestos fibers $/ 10^{6}$ macrophages (Rom et al, 2002).

\section{SilicA}

Crystalline silica (silicone dioxide) is a commonly used construction material. Silica is a well-known respiratory toxin, which may lead to the development of silicosis. Pathological changes due to silica exposure may lead to the development of chronic obstructive pulmonary disease (COPD) (Hnizdo\&Vallyathan, 2003). Silica has been noted to have possible effects on the immune system in both animal and human studies. While dose-dependent, silica may either destroy macrophages or stimulate the immune system. Silica-exposed workers also have an increased risk of scleroderma, believed to be caused via the adjuvant mechanism (Kaminski et al, 2008).

The silica samples collected never exceeded the NIOSH Recommended Exposure Limit (REL) of 0.05mg / $\mathrm{m}^{3}$. This limit is a time-weighted 10 -hour average concentration. Of the nearly 1,800 samples, approximately one percent tested positive for silica. The highest level was $0.03 \mathrm{mg} / \mathrm{m}^{3}$. There were 159 samples from the Ground Zero site and none of these tested positive. These levels are not likely to cause adverse health outcomes. 
However, Lorber et al (2007) discussed that the samples for silica were taken between September 27, 2001 and June 20, 2002. It is possible that on September 11 and the days immediately following, there were significant exposures to respirable silica.

\section{Metals}

There were a number of metals identified in the WTC dust and air samples. These include calcium, iron, zinc, chromium, nickel aluminum, antimony, lead, titanium, and magnesium. The lead ( $\mathrm{Pb}$ ) levels on September 11 were likely elevated, creating a short-term exposure. During late September, there were several days when the lead level at Ground Zero exceeded the EPA's National Ambient Air Quality (NAAQ) Standard. By mid-October, the levels outside Ground Zero reached background levels (Lorber et al, 2007). However, from October through November, 2001, there were still occasional small spikes in the Pb levels at Ground Zero. In dry weight, Pb levels ranged from 142,00 ng/g to 483,500ng/g (Lioy et al, 2002). Calcium (Ca) levels reached the highest levels in October and November. At this time, the total dust levels at Ground Zero were approximately five times greater than the dust levels at the perimeter (Landrigan et al, 2004).

Chromium ( $\mathrm{Cr}$ ) and nickel (Ni) levels never exceeded NIOSH RELs. Nickel levels did exceed the ATSDR recommended levels of $0.2 \mathrm{mcg} / \mathrm{m}^{2}$ once at $.49 \mathrm{mcg} / \mathrm{m}^{2}$. However, it is believed that early exposures when the levels were not documented in the first days may have contributed to the respiratory effects noted from the WTC disaster (Lorber et al, 2007). Nickel is a Category 1 agent in the IARC, documented for lung and nasal cancer. $\mathrm{Cr}(\mathrm{VI})$ is also a Category 1 agent in the IARC, also for lung and nasal cancer. $\mathrm{Cr}(\mathrm{VI})$ may also have synergistic effects with PAHs. "Cr(VI) exposure may enhance chromatin structure-dependent carcinogen + DNA binding. This effect may contribute to the synergism of $\mathrm{Cr}(\mathrm{VI})$ and BPDE on mutagenesis and cell transformation, and may also contribute to the higher incidence of lung cancer in $\mathrm{Cr}(\mathrm{VI})$-exposed populations" (Feng et al, 2003). For the EPA WTC Benchmarks for COPC, $\mathrm{Cr}$ and its compounds are not differentiated, nor did any of the samples separate the compounds in testing (US EPA 2003). Cr dry weight ranged 142,600 ng/g to 182,000 ng/g (Lioy et al, 2002).

\section{CONCLUSION}

While this review is by no means an exhaustive review of the toxicants found in World Trade Center dust and their known adverse health effects, it may help increase interest in the toxicants to which survivors and responders of 9/11 were exposed. In recent years, multiple articles, both peer-reviewed and in the popular press, have focused on the loss of life and livelihood that has accompanied exposure to this toxic mix. Continued research on the known toxicants found in the World Trade Center dust is required to understand its effects on the body. Furthermore, increased knowledge of the adverse health outcomes associated with exposure to toxicants may help to clarify non-WTC exposures to air pollution and the adverse outcomes. We recommend this research continue.

\section{REFERENCES}

Agency for Toxic Substances and Disease Registry. Volatile Organic Compounds. 2008; [http://www.atsdr.cdc. gov/substances/toxchemicallisting.asp?sysid=7] Date accessed: 9/17/12

Alexandrov K, Cascorbi I, Rojas M, Bouvier G, Kriek E, Bartsch H. CYP1A1 and GSTM1 genotypes affect benxo[a] pyrene DNA adducts in smokers' lung: comparison with aromatic/hydrophobic adduct formation. Carcinogensis. 2002;23(12): 1969-1977.

Boffetta P, Jourenkova N, Gustavsson P. Cancer risk from occupational and environmental exposure to polycyclic aromatic hydrocarbons. Cancer Causes Control.1997; 8(3):444-72.

Bowers B, Hasni S, Gruber BL [2010]. Sarcoidosis in World Trade Center rescue workers presenting with rheumatologic manifestations. J Clin Rheumatol16(1):26-27. 
Butt CM, Diamond ML, Truong J, Ikonomou MG, Helm, PA, Stern GA. Semivolatile organic compounds in window films from lower Manhattan after the September $11^{\text {th }}$ World Trade Center attacks. Environ Sci Technol. 2004;38(13): 3514-3524.

Cahill TA, Cliff SS, Perry KD, Jimenez-Cruz M, Bench G, Grant P, Ueda D, Shackelford JF, Dunlap M, Meier M, Kelly PB, Riddle S, Selco J, Leifer R. Analysis of aerosols from the World Trade Center collapse site, New York, October 2 to October 30, 2001. Aerosol Sci Technol. 2004; 38(2):165-183.

Cohen BS, Heikkinen MSA, Hazi Y . Airborne fine and ultrafine particles near the World Trade Center disaster site. Aerosol Sci Technol. 2004; 38(4):338-348.

EPA. Toxicological Effects of Fine Particulate Matter Derived from the Destruction of the World Trade Center. 2002; [http://www.epa.gov/nheerl/wtc/WTC_report_7b3i.pdf].

EPA. World Trade Center Background Study Report Interim Final. 2003a; [http://www.epa.gov/wtc/reports/ background_study_report.pdf].

EPA. World Trade Center Indoor Environment Assessment: Selecting Contaminants of Potential Concern and Setting Health-Based Benchmarks. 2003b; [http://www.epa.gov/wtc/reports/contaminants_of_concern_ benchmark_study.pdf].

Feldman DM, Baron SL, Bernard BP, Lushniak BD, Banauch G, Arcentales N, Kelly KJ, Prezant DJ. Symptoms, respirator use, and pulmonary function changes among New York City firefighters responding to the World Trade Center disaster. Chest. 2004; 125(4):1256-1264.

Feng Z, Hu W, Rom WN, Costa M, Tang, MS. Chromium(VI) exposure enhances polycyclic aromatic hydrocarbonDNA binding at the $\boldsymbol{p} 53$ gene in human lung cells. Carcinogenesis. 2003; 24(4): 771-778.

Fournier J, Pezerat H. Studies on surface properties of asbestos. III. Interactions between asbestos and polynuclear aromatichydrocarbons. Environ Res. 1986;41(1):276-95.

Gargano, L. M., Mantilla, K., Fairclough, M., Yu, S., \&Brackbill, R. M. . Review of non-respiratory, non-cancer physical health conditions from exposure to the World Trade Center Disaster. International journal of environmental research and public health. 2018; 15(2), 253.

Gavett SH, Haykal-Coates N, Chen L, Cohen MD, Costa DL. Respiratory toxicological effects of world trade center fine particulate matter in mice. Toxicol Sci. 2003; 72:287.

Hitt E. The World Trade Center attack and cancer risk: a waiting game. Lancet Oncology. 2001; 2(11):652-652.

Hnizdo E, Vallyathan V. Chronic obstructive pulmonary disease due to occupational silica dust: a review of epidemiological and pathological evidence. Occup Environ Med. 2003; 60(4):237-43.

Horii Y, Jiang Q Hanari N, Lam PK, Yamashita N, Jansing R, Aldous KM, Mauer MP, Eadon GA, Kannan K. Polychlorinated dibenzo-p-dioxins, dibenzofurans, biphenyls, and naphthalenes in plasma of workers deployed at the World Trade Center after the collapse. Environ Sci Technol. 2010; 44(13):5188-5194.

IARC.Benzene. 2012; [http://monographs.iarc.fr/ENG/Monographs/.../mono100F-24.pdf].

Ilgren EB. Health risks from exposures to asbestos, metals, and various chemicals due to collapse of the World Trade Center: An environmental residential survey with a commentary related to Ground Zero workers. Indoor Built Environ. 2001;10(6):361-383.

Izbicki G, Chavko R, Banauch GI, Weiden MD, Berger KI, Aldrich TK, Hall C, Kelly KJ, Prezant DJ [2007]. World Trade Center "sarcoid-like" granulomatous pulmonary disease in New York city fire department rescue workers. Chest 131(5):1414-1423.

American Research Journal of Public Health

Page 7 
A Review of the Toxicants Found in World Trade Center Dust

Kaminski NE, Kaplan BL, Holsapple MP. Toxic responses of the immune system. In Cassett's\&Doull's toxicology: the basic science of poisons. New York: McGraw Hill Medical. 2008; 485-556.

Kelly KJ, Connelly E, Reinhold GA, Byrne M, Prezant DJ. Assessment of health effects in New York City firefighters after exposure to polychlorinated biphenyls (PCBs) and polychlorinated dibenzofurans (PBDFs): the Staten Island transformer fire health surveillance project. Arch Environ Health. 2002;57(4): 282-293.

Kriek E, Rojas M, Alexandrov K, Bartsch H. Polycyclic aromatic hydrocarbon-DNA adducts in humans: relevance as biomarkers for exposure and cancer risk. Mutat Res. 1998;400: 215-231

Lambroussis CG, Soares BD, Perez S, Gaipa D, Elie AL, Ament CM, Rouf FT, Bassa LM, DiLorenzo AM. Indications of potential toxic/mutagenic effects of World Trade Center dust on human lung cell cultures. OnLine J Biol Sci, 2009;9(3): 81-85.

Landrigan PJ, Lioy PJ, Thurston G, Berkowitz G, Chen LC, Chillrud SN, Gavett SH, Georgopoulos PG, Geyh AS, Levin S, Perera F, Rappaport SM, Small C. Health and environmental consequences of the world trade center disaster. Environ Health Perspect. 2004; 112(6):731-739.

Lioy PJ, Weisel CP, Millette JR, Eisenreich S, Vallero D, Offenberg J, Buckley B, Turpin B, Zhong M, Cohen MD, Prophete C, Yang I, Stiles R, Chee G, et al. Characterization of the dust/smoke aerosol that settled east of the World Trade Center (WTC) in lower Manhattan after the collapse of the WTC 11 September 2001. Environ Health Perspect. 2002; 110(7):703-714.

Lorber M, Gibb H, Grant L, Pinto J, Pleil J, Cleverly D. Assessment of inhalation exposures and potential health risks to the general population that resulted from the collapse of the World Trade Center towers. Risk Ana. 2007; 27(5):1203-21.

Marchanda LS, St-Hilaire S, Putnamb EA, Servea KM, Pfaua JC. Mesothelial cell and anti-nuclear autoantibodies associated with pleural abnormalities in an asbestos exposed population of Libby MT. Toxicology Letters. 2012; 208: 168- 173

Markowitz SB, Garibaldi K, Lilis R, Landrigan PJ. Asbestos exposure and fire fighting. Ann NY Acad Sci, 1991; 643: 573-577.

McGee JK, Chen LC, Cohen MD, Chee GR, Prophete CM, Haykal-Coates N, Wasson SJ, Conner TL, Costa DL, Gavett SH. Chemical analysis of World Trade Center fine particulate matter for use in toxicologic assessment. Environ Health Perspect. 2003; 111(7):972-980.

Moline J, Herbert R, Nguyen N. Health consequences of the September 11 World Trade Center attacks: a review. Cancer Invest. 2006;24(3):294-301.

National Toxicology Program. Benzene. 2011; [ntp.niehs.nih.gov/ntp/roc/twelfth/profiles/Benzene.pdf]

NIOSH. World Trade Center chemicals of potential concern and selected other chemical agents. 2012; [http:// www.cdc.gov/niosh/docs/2012-115/]

Offenberg JH, Eisenreich SJ, Chen LC, Cohen MD, Chee G, Prophete C, Weisel C, Lioy PJ. Persistent organic pollutants in the dusts that settled across lower Manhattan after September 11, 2001. Environ Sci Technol. 2002;37:502-508.

Olson, DA,Norris, GN, Seila, RL, Landis, MS, Vette, AF. Chemical characterization of volatile organic compounds near the World Trade Center: Ambient concentrations and source apportionment. Atmos Environ. 2003; 41: 5673-5683

Olson DA, Norris GA, Landis MS, Vette AF. Chemical characterization of ambient particulate matter near the World Trade Center: elemental carbon, organic carbon, and mass reconstruction. Environ Sci Technol. 2004; 38: 4465-4473.

American Research Journal of Public Health

Page 8 
Olson DA, Norris GA. Chemical characterization of ambient particulate matter near the World Trade Center: Source apportionment using organic and inorganic source markers. Atmos Environ. 2008; 42(31):73107315 .

Olson DA, Norris GA, Seila RL, Landis MS, Vette AF. Chemical characterization of volatile organic compounds near the World Trade Center: Ambient concentrations and source apportionment. Atmos Environ. 2007; 41(27):5673-5683.

Pariselli F, Sacco MG, Ponti J, Rembges D. Effects of toluene and benzene air mixtures on human lung cells (A459) Exp Toxic Pathol. 2009; 61: 381-386.

Pelucchi C, Negri E, Gallus S, Boffetta P, Tramacere I, La VecchiaC. Long-term particulate matter exposure and mortality: a review of European epidemiological studies. BMC Public Health. 2009; 9: 453.

Perera FP, Tang D, Rauh V, Lester K, Tsai WY, Tu YH, Weiss L, Hoepner L, King J, Del Priore G, Lederman SA. Relationships among polycyclic aromatic hydrocarbon-DNA adducts, proximity to the World Trade Center, and effects on fetal growth. Environ Health Perspect. 2005a; 113(8):1062-1067.

Perera FP, Tang D, Whyatt R, Lederman SA, Jedrychowski W. DNA damage from polycyclic aromatic hydrocarbons measured by benzo[a]pyrene-DNA adducts in mothers and newborns from Northern Manhattan, the World Trade Center Area, Poland, and China. Cancer Epidemiol Biomarkers Prev. 2005b; 14(3):709-714.

Perera FP, Tang D, Rauh V, Tu YH, Tsai WY, Becker M, Stein JL, King J, Del Priore G, Lederman SA. Relationship between polycyclic aromatic hydrocarbon-DNA adducts, environmental tobacco smoke, and child development in the World Trade Center cohort. Environ Health Perspect. 2007; 115(10):1497-1502.

Pfau JC, Sentissi JJ, Weller G, Putnam EA. Assessment of autoimmune responses associated with asbestos exposure in Libby, Montana, USA. Environ Health Perspect. 2005; 113(1):25-30.

Pleil JD, Vette AF, Johnson BA, Rappaport SM. . Air levels of carcinogenic polycyclic aromatic hydrocarbons after the World Trade Center disaster. Proc Natl Acad Sci U S A. 2004; 101:11685-11688.

Rayne S. Using exterior building surface films to assess human exposure and health risks from PCDD/Fs in New York City, USA, after the World Trade Center attacks. J Hazard Mater. 2005; 127:33-39.

RomWN, Weiden M, Garcia R, Ting AY, Vathesatogkit P, Tse DB, McGuinness G, Roggli V, Prezant D. Acute eosinophilic pneumonia in a New York City firefighter exposed to World Trade Center dust. Am J Respiratory Crit Care Med. 2002; 166(6):797-800.

Rom WN, Reibman J, Rogers L, Weiden MD, Oppenheimer B, Berger K, Goldring R, Harrison D, Prezant D. Emerging exposures and respiratory health: World Trade Center dust. Proc Am Thorac Soc. 2010; 7(2):142-145.

Samet JM, Geyh AS, Utell MJ. The legacy of World Trade Center dust. N Engl J Med. 2007; 356(22):2233-2236.

White SS, Birnbaum LS. An overview of the effects of dioxins and dioxin-like compounds on vertebrates, as documented in human and ecological epidemiology. J Environ Sci Health C Environ CarcinogEcotoxicol Rev. 2009; 27(4):197-211.

Witschi HR, Pinkerton KE, Van Winkle LA, Last JA. Toxic responses of the respiratory system. In Cassett's\&Doull's toxicology: the basic science of poisons. New York: McGraw Hill Medical. 2008; 609-630.

Citation: Bernadette Royce, Ira S. Richards, "A Review of the Toxicants Found in World Trade Center Dust". American Research Journal of Public Health; 1(1): 1-9.

Copyright (c) Bernadette Royce, Ira S. Richards, This is an open access article distributed under the Creative Commons Attribution License, which permits unrestricted use, distribution, and reproduction in any medium, provided the original work is properly cited. 